\title{
大腿骨に発生した骨膜下ガングリオン一例
}

長崎大学医学部整形外科

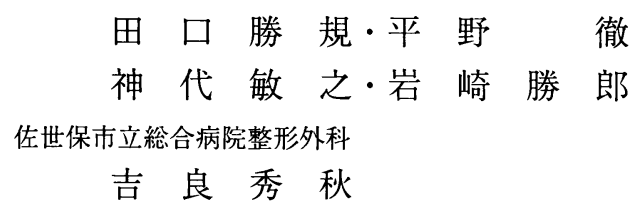

A case of Periosteal Ganglion of the Femur

by
Katsuki Taguchi, Toru Hirano, Toshiyuki Kumashiro and Katsurou Iwasaki
Department of Orthopaedic Surgery,
Nagasaki University School of Medicine

\section{Hideaki Kira}
Department of Orthopaedic Sugery, Sasebo City Sogo Hospital

\begin{abstract}
We present a case of periosteal ganglion in the distal metaphysis of the femur, in a 50 years old woman, which was confirmed by the surgery. Radiograms showed the cortical erosion and spicula formation mimicing the malignant bone tumors. However, no increased uptake was seen in the lesion by ${ }^{99_{\mathrm{m}}} \mathrm{Tc}$-MDP scintigraphy. MRI suggested periosteal ganglion from the findings of its periosteal location and the content of low signal intensity in $\mathrm{T}_{1}$ and high signal intensity in $\mathrm{T}_{2}$.

Those findings have been discussed on the points of the image diagnosis.
\end{abstract}

は じめに

ガングリオンは一般的には関節周囲の軟部組織より 発生する疾患であるが, 我々は, 単純 X線で悪性骨腫 骨腫瘍との鑑別が非常に困難であった大腿遠位部発生 の骨膜下ガングリオンを一例経験したので, その術前 診断のポイントにつき若干の文献的考察を加えて報告 する.

\section{症例}

症例 : 50 才, 女性.

主訴 : 左膝部痛.

現病歴: 平成 2 年 2 月初旬, 階段昇降時に左膝部痛 出現. 平成 2 年 5 月, 佐世保市立総合病院を受診し, 単純 X 線調査で左大腿骨遠位部に異常陰影を指摘され, 当科紹介となった.
既往歴及び家族歴 : 特記すべき事項はなかった. 現症 : 左大腿骨遠位部に腫瘤を触知せず，圧痛・腫 脹・熱感はなかった，左膝関節の可動域は正常であっ た.

入院検查所見 : Al-P 147 (IU/l), Ca $9.1(\mathrm{mg} / \mathrm{dl})$, P $4.2(\mathrm{mg} / \mathrm{dl})$, LDE 454 (IU/l), 血沈 $12 / 34$, $\mathrm{CRP}($ (一) と LDH の軽度上昇がみられた。一般検 血, 肝・腎機能は正常だった.

単純X線所見・左大腿遠位内側に骨皮質の侵食像と, 肉太いスピクラの形成を認めた（図 1$)$.

単純 CT 所見 : 左大腿骨遠位部の内側から後面にか けて, 骨皮質表層にCT 值 50 前後の境明瞭な腫瘤を 認め, 皮質の侵食像を伴っていた（図 2 ).

骨シンチ所見 : 病素部に異常集積像はみられなかっ た（図 3 ).

MRI 所見: 横断面で, 腫瘤 T1 強調像で low in- 


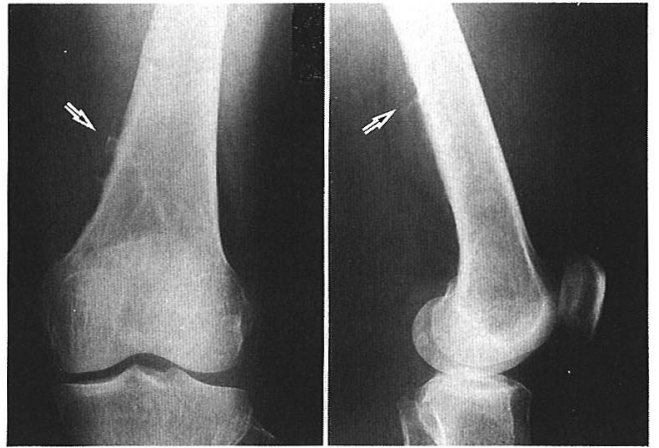

図 1 初診時単純X線像. 左大腿骨遠位部内側にスピ クラの形成を認める.

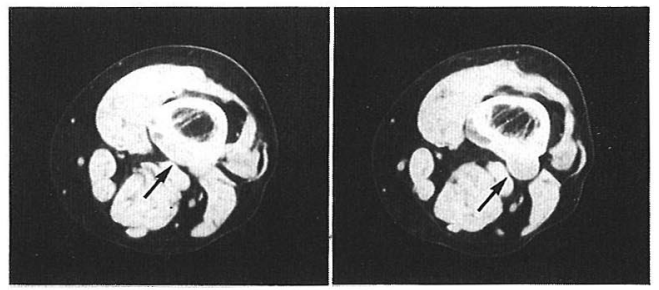

図 2 単純 $\mathrm{CT}$ 像では, 皮質の侵食を伴う腫瘤を認め る.

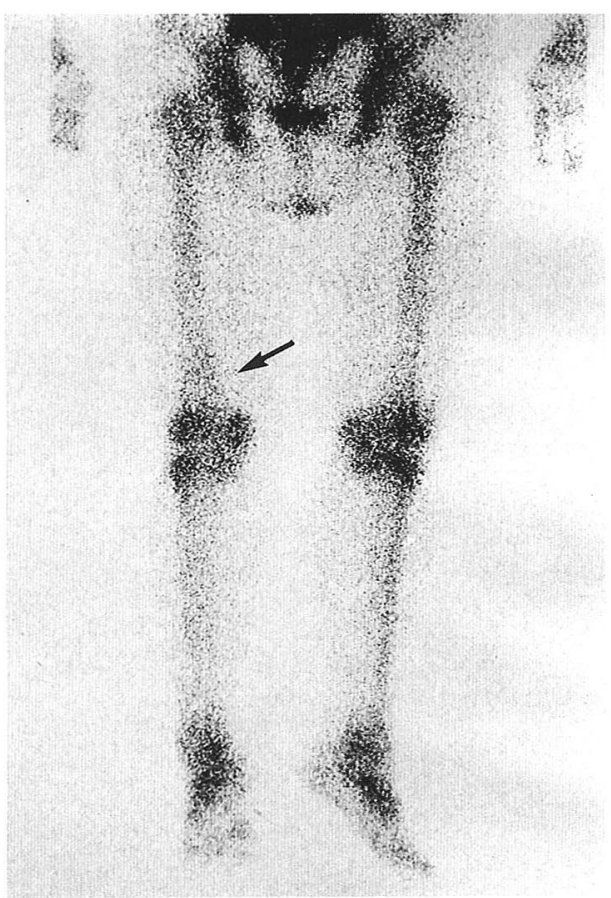

図 3 骨シンチ後面像. 異常集積はない.
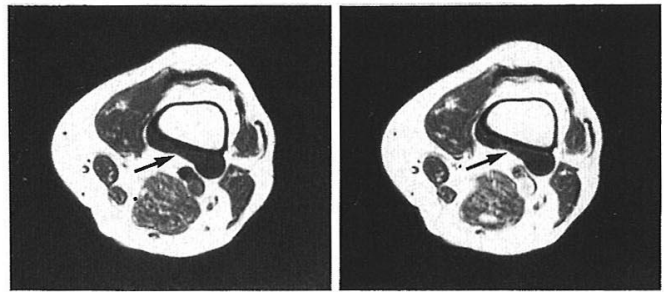

図 $4 \mathrm{~T} 1$ 強調像（左）でlow intensityを示し，Gd． (右）によりエンハンスされていない.
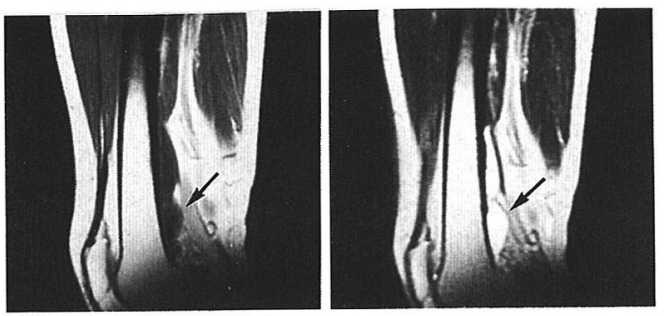

図 $5 \mathrm{~T} 1$ 強調像（左）で low，T2 強調像（右）で high intensityを示している. 䯣内は正常.

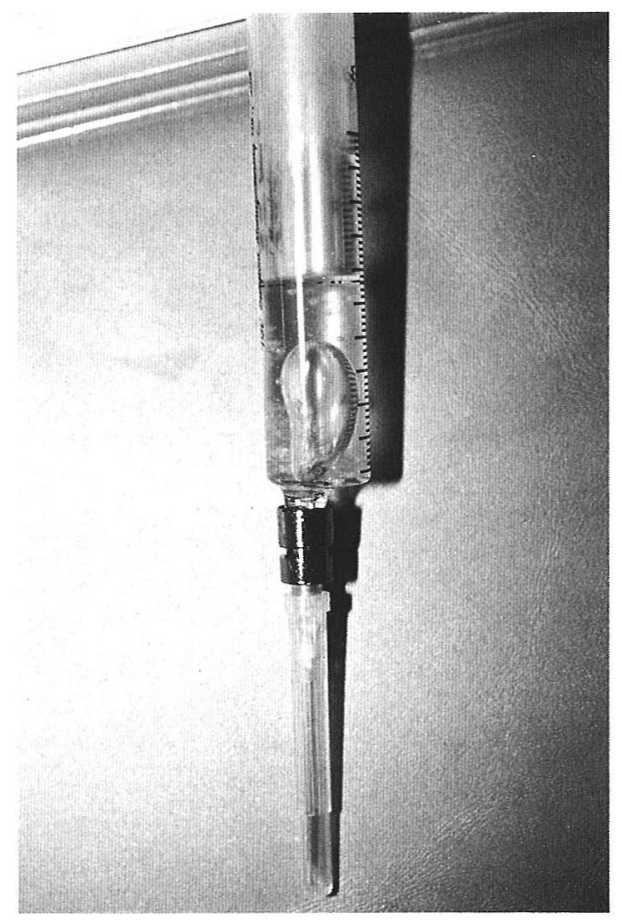

図 6 吸引したゼリー状物質. 


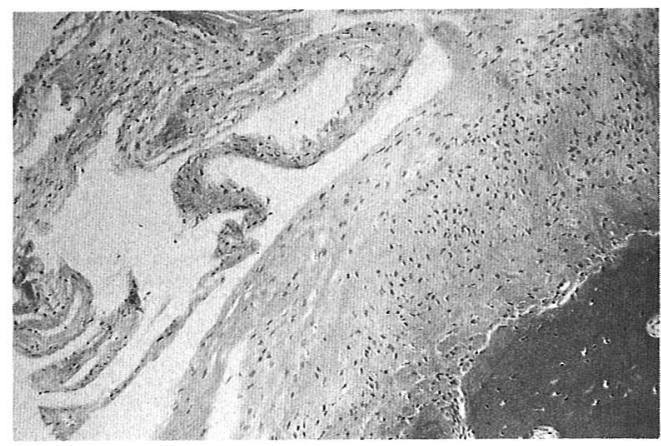

図7壁は膠原化した繊維性結合組織より成る. (HE 染色 : $\times 100)$

tensity を示し，ガドリニムによる造影効果は認めな かった（図 4 )。矢状面では, T1 強調像で low, T2 強調像で high intensity を示し, 表面は骨膜と同様 の膜様構造で被われていた。髄内には異常はなかった (図 5 ).
以上の所見，特に MRI 所見から，骨膜下への液状 物質の貯留が最も疑われ，術前に骨膜下ガングリオン である可能性が示唆された。

手術時所見 : 腰椎麻酔下に左大腿遠位内側部に7 $\mathrm{cm}$ 程の縦皮切を加え大腿骨に達すると，骨膜に被わ れた液状物質の貯溜が認められた，注射器で同部より 黄色透明のゼリー状物質を吸引し（図6）, ガングリ オンである事を確認した後，表面を被っていた骨膜を 可及的に切除し, 病巣择爬を行った。

組織学的床見 : 軟部組織に発生したガングリオンと 同様，その壁と膠原化した繊維性結合識よりなってい た（図 7 ).

以上より骨膜下ガングリオンと診断した。

\section{考察}

骨膜下ガングリオンについての報告は極めて少なく， 我々が検索しえた症例は国内外合わせても 19 例にす ぎない（表 1 ).

表 1 REVIEW OF THE LITERATUERS

\begin{tabular}{|c|c|c|c|c|}
\hline 症例 & 年齢, 性 & 発生部位 & 単純X線異常所見 & 報 告 者 \\
\hline 1 & $38, \mathrm{M}$ & 脛骨近位部 & $(-)$ & Byers $(1970)^{2)}$ \\
\hline 2 & $42, \mathrm{M}$ & " & $(-)$ & " \\
\hline 3 & $37, \mathrm{M}$ & " & $(-)$ & " \\
\hline 4 & $58, \mathrm{M}$ & " & $(-)$ & " \\
\hline 5 & $36, \mathrm{M}$ & " & $(-)$ & Kay $(1971)^{9)}$ \\
\hline 6 & $66, \mathrm{~F}$ & " & 境界明瞭な骨透明巣 & $(1972)^{8)}$ \\
\hline 7 & $70, \mathrm{M}$ & " & 境界明瞭な骨透明巣 & " \\
\hline 8 & $72, F$ & " & $(-)$ & $(1983)^{7)}$ \\
\hline 9 & $50, \mathrm{M}$ & " & $\begin{array}{r}\text { 骨膜反応 } \\
\text { 骨皮質の侵食像 } \\
\end{array}$ & $\begin{array}{l}\text { McCarthy } \\
\qquad(1983)^{12)}\end{array}$ \\
\hline 10 & $55, \mathrm{M}$ & $"$ & 骨膜反応 & $"$ \\
\hline 11 & $67, \mathrm{~F}$ & " & 軟部腫瘤（CT） & Kenan $(1987)^{10)}$ \\
\hline 12 & $68, \mathrm{M}$ & $"$ & 骨皮質の侵食像 & Barry $(1990)^{1)}$ \\
\hline 13 & 44, M & 脛骨遠位部 & 骨皮質欠損 & Fisk $(1949)^{3)}$ \\
\hline 14 & $68, \mathrm{M}$ & $"$ & 骨表面の虫食い像 & $(1985)^{6)}$ \\
\hline 15 & $51, \mathrm{M}$ & 腓骨遠位部 & 骨透亮像 & 桜井 $\quad(1982)^{13)}$ \\
\hline 16 & 37, M & 大腿骨遠位部 & $\begin{array}{r}\text { 骨膜反応 } \\
\text { 骨皮質の侵食像 }\end{array}$ & $\begin{array}{l}\text { McCarthy } \\
\text { (1983) }\end{array}$ \\
\hline 17 & $43, \mathrm{M}$ & " & $\begin{array}{r}\text { 骨膜反応 } \\
\text { 骨皮質の侵食像 } \\
\end{array}$ & $\begin{array}{l}\text { Kolär } \\
\qquad(1986)^{11)}\end{array}$ \\
\hline 18 & $39, \mathrm{M}$ & 橈骨遠位部 & $\begin{array}{r}\text { 骨膜反応 } \\
\text { 骨皮質の侵食像 } \\
\end{array}$ & $\begin{array}{l}\text { Grange } \\
\qquad(1978)^{4)}\end{array}$ \\
\hline 19 & $8, \mathrm{~F}$ & " & $\begin{array}{r}\text { スピクラ形成 } \\
\text { 骨皮質の侵食像 }\end{array}$ & $\begin{array}{l}\text { Heyse-Moors } \\
\qquad(1979)^{5)}\end{array}$ \\
\hline
\end{tabular}


その 19 例を総括してみると, 発症年令は 30 歳以上 に多く, 発生部位は脛骨近位部が 19 例中 12 例と圧倒 的だったまた，X線所見では，骨膜あるいは骨皮質 の変化を伴うものが 19 例中 10 例と半数以上を占め, 悪 性骨腫瘍との鑑別が問題となっていた1) 3) 4) 5) 6) 1112213). 我々も最初, 単純 $X$ 線上, 骨膜辺縁や骨膜下に発生す る病変, 例えば Osteosarcoma, Metastatic Bone Tumor な゙の悪性腫瘍から, Neurofibroma, Aneuryzmal Bone Cystなどの良性病変まで, 多くの疾 患を疑った，しかしながら CT，骨シンチ，MRI と 精查を進めて行くうちに，悪性腫瘍などの浸潤破壊性 の強い病変は否定的となり，術前に骨膜下ガングリオ ンである可能性が示唆された．現在までの報告では， 骨膜下ガングリオンの MRI 所見の記載はなく，また 術前に診断がなされた症例もなかった．本症例で見ら れた所見及び報告例も所見から，骨膜下ガングリオン の臨床的及び画像診断的特徵は以下の様な事であった.

(1)発生部位は, 長幹骨の骨幹端及び骨端で, 脛骨近 位部に好発する。

(2)単純 X線像では，スピクラ様の骨膜反応や骨皮質 の侵食像が見られる.

(3)単純 CT 像では，骨皮質表面の腫瘤として認めら れ, 皮質の侵食像を伴う。

(4)骨シンチは, 病変部への異常集積を認めない.

(5) MRI では，病変部は $\mathrm{T} 1$ 強調像で低信号域，T2 強調像で高信号域を示し，ガドリニウムによる造影効 果はみられない。腫瘤表面には骨膜から連続する, 膜 様構造物を認める．髄内の異常所見はない。

$$
\text { ま と め }
$$

今回我々は，大腿骨に発生した極めて稀な骨膜下ガ
ンリオンを一例経験したので報告した．本症例の質的 診断には MRI が特に有用で，骨シンチ，CT などの 画像検査との併用により術前診断は可能であることが 示唆された。

\section{文献}

1) Barry,M., and Hoyse-Moore, G.H.: Acute haemorrhage into a subperiosteal ganglion. J. Bone Joint Surg., 72-B : 519, 1990.

2) Byers, P.D., and Wadsworth, T.G.: Perisoteal ganglion. J.Bone Joint Surg, 52-B : 290-295, 1970.

3) Fisk. G. R.: Bone concavity caused by a ganglion. J. Bone Joint Surg., 31-B : 220-221, 1949.

4) Grange, W. J.: Subperiosteal ganglion. J. Bone Joint Surg., 60-B : 124-125, 1978.

5) Heyse-Moore, G. H., and Grange, W. J.: Case report 82. Skeletal Radiol., $3:$ 255-256, 1979.

6）桶口 理・他：左下腿に急激に発生し脛骨・腓骨と広 範に骨破壊を呈したPeriosteal ganglionの 1 例. 整形外 科と災害外科, $34: 768-771,1985$ 。

7）稲村信昌・他：脛骨に発生したPeriosteal ganglion の 1 例. 北海道整災外誌, $28: 99,1983$.

8）梶山英彦・他：骨腫瘍と誤られた Periosteal ganglion の 2 例. 整形外科, $23: 388-390,1972$.

9) Kay, N. R. M. Sub-periosteal ganglia. Acta Orthop. Suandinav., 42 : 173-177, 1971.

10) Kenan, S. et al.: Periosteal ganglion-case report and review of the literature. Bull. Host. Jt. Dis. Orthop. Inst., $47: 46-51,1987$.

11) Kolar, J. et al.: Periosteal ganglion. Fortschr. Rontgenstr., 144 : 234-236, 1986.

12) McCarthy, E. F. et.: al Periosteal ganglion-a cause of cortical bone erosion. Skeletal Radiol., 10:243246, 1983.

13）桜井公也・他：腓骨に発生した Periosteal ganglion の 1 例. 中部日整整災外誌, $25: 1976,1982$. 